\title{
Health complaints and use of medicines among adolescents in Malta
}

Rita DARMANIN ELLUL, Maria CORDINA, Anton BUHAGIAR, Anthony FENECH, Janet MIFSUD. Received (first version): 17-Mar-2008 Accepted: 18-Aug-2008

\begin{abstract}
${ }^{*}$
Objective: To investigate self-reported health complaints and the use of medicines among adolescents in Malta.

Methods: A self-administered questionnaire was used to survey self-reported health complaints, the use and the sources of medicines that had been accessed, during the preceding 3 months among adolescents attending secondary schools in Malta. A stratified random sample design generated a sample size of 514 students. The health complaints and use of medicines that were investigated included ear problems/hay fever/cold/cough, headache, skin problems, sport injuries, indigestion/diarrhoea/constipation, eye problems and menstrual pain (for girls). The use of vitamins and antibiotics was also investigated.

Results: A total of 477 students participated in the final data collection. Correct information was submitted by 474 students, (aged $14-16$ years), who formed the analytical sample, of which $53.8 \%$ were girls. The students reported a mean number of 2.70 ( $S D=1.39$ ) out of a total of 7 health complaints and $90.3 \%$ reported using at least 1 medicine during the preceding 3 months. The community pharmacy was cited as the most commonly accessed source for most of the medicines that were investigated. A proportion of $24.3 \%$ of the students had taken at least 1 medicine without adult guidance during the preceding 3 months. Almost $10 \%$ of those who had taken antibiotics, had accessed them from the home medicine cabinet.

Conclusion: A high proportion of adolescents in Malta reported the use of medicines to alleviate the symptoms of common health complaints. This result is concordant with previous research carried out in the United Kingdom, Germany, Slovakia and Kuwait. A considerable proportion of students in this study had obtained medicines without adult guidance and accessed antibiotics from the home medicine cabinet. This highlights the importance of carefully designed education programs for
\end{abstract}

\footnotetext{
*Rita DARMANIN ELLUL. MSc. Department of Clinical Pharmacology and Therapeutics, University of Malta, Msida (Malta).

Maria CORDINA. PhD. Department of Pharmacy, University of Malta. Msida (Malta).

Anton BUHAGIAR. PhD. Department of Mathematics, University of Malta. Msida (Malta).

Anthony FENECH. PhD. Department of Clinical

Pharmacology and Therapeutics, University of Malta, Msida (Malta).

Janet MIFSUD. PhD. Department of Clinical

Pharmacology and Therapeutics, University of Malta, Msida (Malta).
}

adolescents that will integrate information about the proper use of medicines.

Keywords: Adolescent. Drug Utilization. Malta.

\section{PROBLEMAS DE SALUD Y USO DE MEDICAMENTOS ENTRE ADOLESCENTES EN MALTA}

\section{RESUMEN}

Objetivo: Investigar los problemas de salud y el uso de medicamentos auto-comunicado entre adolescentes en Malta.

Métodos: Se usó un cuestionario auto-administrado para indagar los problemas de salud autocomunicados, el uso y las fuentes de medicamentos a los que habían accedido durante los 3 meses precedentes al estudio, adolescentes que asisten a escuelas secundarias en Malta. Un muestreo estratificado aleatorio generó un tamaño de muestra de 514 estudiantes. Los problemas de salud y el uso de medicamentos que se investigaron incluían problemas de oído/fiebre del heno/resfriado/tos, dolor de cabeza, problema sde piel, heridas de deportes, indigestión/diarrea/estreñimiento, problemas de ojos, y dolor menstrual (en niñas). También se investigo el uso de vitaminas y antibióticos.

Resultados: Un total de 477 estudiantes participaron en el final de la recogida de datos. Se envió información correcta en 474 estudiantes (edad 14-16 años) que formaron la muestra estudiada, de los que el 53,8\% eran niñas. Los estudiantes comunicaron una media de 2,70 $(\mathrm{DE}=1,39)$ de los 7 problemas de salud y el 90,3\% comunicó que usaba al menos un medicamento en los últimos 3 meses. La farmacia comunitaria fue la fuente más comúnmente usada para la mayoría de los medicamentos investigados. Un $24,3 \%$ de los estudiantes había tomando al menos 1 medicamento sin control de un adulto en los últimos 3 meses. Casi el 10\% de los que habían tomado antibióticos, los había conseguido en el botiquín casero.

Conclusión: Una alta proporción de adolescentes en Malta comunicó el uso de medicamentos para aliviar síntomas de problemas de salud comunes. Este estudio es concordante con investigaciones anteriores realizadas en Reino Unido, Alemania, Eslovaquia y Kuwait. Una considerable proporción de estudiantes en este estudio había obtenido medicamentos sin control de adultos y accedió a los antibióticos en el botiquín casero. Esto remarca la importancia de el diseño cuidadoso de programas d educación para los adolescentes que integren 
información sobre el uso correcto de medicamentos.

Palabras clave: Adolescente. Utilización de medicamentos. Malta.

\section{INTRODUCTION}

The period of adolescence is a period that is marked by anxiety associated with physical growth, significant psychological development and changes in personal relationships. ${ }^{1}$ The stresses that adolescents experience may manifest themselves in psychosomatic health complaints. Research among adolescents based on self-reported health indicators shows a considerably high prevalence of health problems. ${ }^{2-4}$ For example, in a study carried out among Slovak adolescents, $41.6 \%$ of the boys and $61.7 \%$ of the girls had experienced 2 or more health complaints during the preceding month. ${ }^{4}$ Investigation of self-reported health complaints is important, since perceptions about health motivate adolescents to seek medical advice and use medicines, irrespective of the physical conditions underlying these perceptions. ${ }^{5}$

It is clear that the use of medicines, in particular that which takes place without adult guidance, is

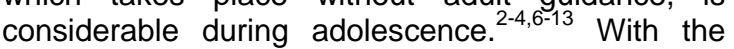
development of formal operational thinking, the adolescent often engages in autonomous health behaviours. ${ }^{14}$ For instance, in a Brazilian study, $49.5 \%$ of $14-20$ year-olds had made use of medicines during the preceding week. ${ }^{13}$ In another study carried out in the US, $29.2 \%$ of $15-18$ year-old girls reported having borrowed and/or shared prescription medicines. ${ }^{15}$

Medicine consumption patterns vary across different age groups. Studies have shown that the consumption of medicines is highest among infants (0-1 year) and decreases until the beginning of adolescence from where it starts to increase again. ${ }^{6}$ However, school-based education about the proper use of medicines is rarely given any importance. ${ }^{16}$

This study was thus aimed at investigating adolescents' health complaints and medicine consumption patterns in a small island state, Malta. This research investigated: (1) the prevalence of self-reported health complaints, (2) the consumption of commonly used medicines, including that which had taken place autonomously, and (3) the sources of medicines that had been accessed among Maltese adolescents during the preceding 3 months.

\section{METHODS}

A self-administered questionnaire was used to survey health complaints and the use of medicines by 14-16 year-old adolescents attending their fourth year of secondary education in public school Junior Lyceums during the period from March to May 2005. Entrance to Junior Lyceums is through a competitive exam, thus making the students a very homogenous group in terms of mental ability and language fluency. The total population of fourthformers attending Junior Lyceums in Malta in 2005 was 1808. This represented $33.3 \%$ of the total adolescents in that age range in Malta. In order to estimate the number of students required to answer the questionnaire that would ensure statistical validity, the most sensitive question in the questionnaire was determined by a pilot study, assuming $95 \%$ confidence and $80 \%$ power. This was taken to have an expected value of $3.7 \%$, thus a sample size of 455 students was calculated using Statcalc in Epi Info (Version 6), accepting an error of $1.5 \%$.

In order to obtain a representative sample, the whole population of fourth-formers attending Junior Lyceums in Malta was stratified by gender and geographical area of residence. Whole classes were than selected by random sampling in order to ensure that the calculated target sample size was reached. The population size generated by stratified random sampling was 514 students distributed over 8 schools. Data collection was carried out during regular class periods under the investigator's supervision. Informed consent was obtained before distributing the questionnaires to the students. The self-administered questionnaires were answered anonymously by the students and returned in sealed envelopes. The students took approximately 30 minutes to complete the questionnaire. Sociodemographic information was collected on gender, month and year of birth and area of residence. Social class variation was measured by means of a family affluence scale that had been established by the World Health Organization (WHO). ${ }^{17,18}$

The data presented in this specific study which formed part of a larger study, is restricted to the descriptive analysis of the following items: subjective health complaints, use of medicines and sources of medicines. The students were asked to fill in a questionnaire in Maltese about the health complaints they had experienced during the preceding 3-month period from a checklist. This list was compiled by the authors after consulting published research that investigated health complaints among adolescents. ${ }^{8-10}$ The health complaints that were included in this study were those of most relevance to the local scenario and for which over-the-counter medicines were available. The list consisted of ear problems/hay fever/cold/cough, headache, skin problems, indigestion/diarrhoea/constipation, sport injuries, eye problems and menstrual pain (for girls). Hay fever and eye problems were included in view of the high prevalence of seasonal allergies and irritations associated with spring, the season during which the survey was conducted. ${ }^{19}$

Furthermore, the students were asked about the related use of medicines for the health complaints they had experienced and also about their use of vitamins during the same preceding 3 months. Since the authors wished to investigate the sources from which antibiotics were obtained among the study population, a question was included about the 
use of these prescription medicines during the preceding 3 months.

Students were asked whether they had obtained the specific medicine from a community pharmacy, a parent/adult relative, a friend/schoolmate or from the home medicine cabinet. The students who marked the last option were in addition asked whether they had obtained the medicine with or without help from adult relatives. The answers about sources of medicines were further subdivided into 2 categories: those students who had obtained at least 1 medicine with adult guidance and those who had obtained at least 1 medicine without adult guidance, during the preceding 3 months.

In order to check for congruency of meaning, the questionnaire that had been originally drafted in English, was translated to Maltese and backtranslated to English. Ethical approval for the study was obtained from the Ministry of Education and the Research Ethics Committee of the University of Malta. The questionnaire was pre-tested with a small number of students to ensure clarity of meaning and relevance. In the original questionnaire, the questions about headache and menstrual pain in the checklist for health complaints were not separate but were grouped under a general term 'pain not caused by sports.' During the pre-testing session, girls pointed out that they had experienced both headaches and menstrual pains in the preceding 3 months and would have preferred if these items were separate. The questionnaire was subsequently modified to separate the health complaints and the relevant use of medicines to reflect the students' suggestions.

The data was processed using PC90 (BMDP Statistical Software, 1990). Percentages were calculated for all the nominal categories of the replies given. The sum and mean scores for health complaints and use of medicines were also calculated. When calculating the scores, a value of 1 was awarded for each health complaint and type of medicine. Means in the data provided are presented together with the standard deviation about the mean.

The Pearson correlation coefficient was used to report the association between the degree of medication and number of health complaints. Since the participants did not consistently respond to every item on the questionnaire, there may be differences in the value of $n$ (the total population of respondents), depending on the question. The level of statistical significance was taken at $\mathrm{p}=0.05$.

\section{RESULTS}

A total of 477 students were present on the days of data collection and all of them returned the questionnaire. Three of the questionnaires were not correctly submitted by the respondents, leading to an actual sample size of 474 . The age of the students ranged from 14 to 16 years (mean $=15.22$ years, $S D=0.41)$. A total of 255 students $(53.8 \%)$ were girls. From a total of 472 respondents, 175 $(37.1 \%), 254(53.8 \%)$ and $43(9.1 \%)$ students ranked low, medium and high respectively according the WHO family affluence scale. ${ }^{17,18}$

A breakdown of the prevalence of self-reported health complaints during the preceding 3 months for the subjects is given in Table 1. A total of 459 students $(97.0 \%, n=473)$ had experienced at least 1 health complaint out of a total of 7 health complaints including menstrual pain (mean $=2.70$ health complaints, $S D=1.39$ ). One hundred and fifty two girls $(59.6 \%$ of the total girl population) reported menstrual pain. The most prevalent health complaints experienced by the study population were ear problems/hay fever/cold/cough, headache and skin complaints. The prevalence of the intake of medicines for the corresponding health complaints is also illustrated in Table 1. In addition, 102 students $(21.5 \%, \mathrm{n}=474)$ had taken vitamins, 91 students $(19.2 \%)$ had taken antibiotics, while 70 girls $(27.5 \%$ of the total girl population) had taken medicines for menstrual pain. With regard to the overall use of medicines, a total of 428 students $(90.3 \%)$ had used between 1 to 9 types of medicines including those used for menstrual pain during the preceding 3 months (mean=2.54 medicines, $S D=1.68$ ). The most prevalent use of medicines had been that for ear problems/hay fever/cold/cough, headache and skin complaints. There was a statistically significant positive correlation between the number of physical health complaints and number of medicines used $(r=0.623$, $p<0.001$ for boys and $r=0.573, p<0.001$ for girls).

\begin{tabular}{|c|c|c|}
\hline Health complaint & $\begin{array}{l}\text { Prevalence of health complaint, } \\
\text { No. }(\%) \text { of students } \\
(n=473)\end{array}$ & $\begin{array}{l}\text { Prevalence of use of medicine for } \\
\text { the corresponding health } \\
\text { complaint, No. }(\%) \text { of students } \\
(n=474)\end{array}$ \\
\hline Ear/hay fever/cold/cough & $375(79.3)$ & $312(65.8)$ \\
\hline Headache & $324(68.5)$ & $284(59.9)$ \\
\hline Skin & $161(34.0)$ & $147(31.0)^{\star}$ \\
\hline Indigestion/diarrhoea/constipation & $128(27.1)$ & $76(16.0)$ \\
\hline Sport injuries & $84(17.8)$ & $79(16.7)$ \\
\hline Eye & $55(11.6)$ & $43(9.1) \dagger$ \\
\hline
\end{tabular}




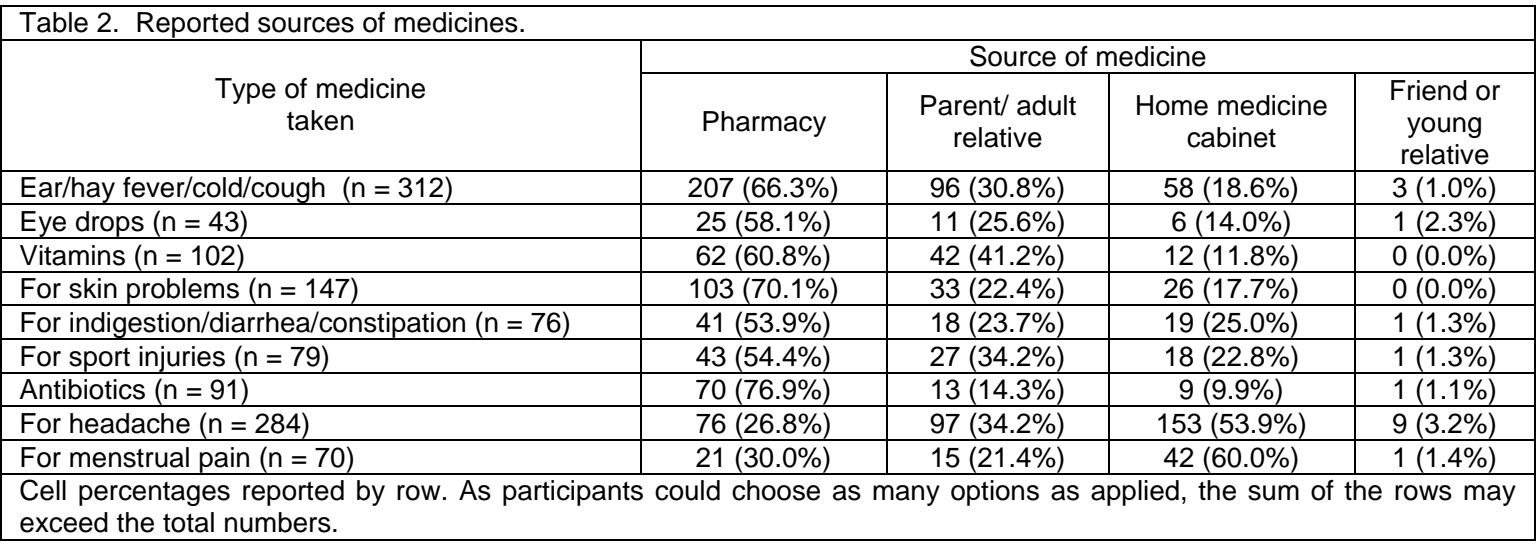

The pharmacy was cited as being the most common source from which all medicines had been accessed during the preceding 3 months except for medicines for headache and menstrual pain, which were mostly obtained from the home medicine cabinet. Parents/adult relatives were generally the second most common source of medicines. The least common sources for all medicines were friends or young relatives (Table 2). A total of 283 students had obtained their medicine from the home medicine cabinet during the preceding 3 months. Of these, $183(64.7 \%)$ students had asked for help from adults before getting the medicine.

Further analysis showed that of those who had taken medicine $(n=428)$, a total of $414(96.7 \%)$ students had obtained at least 1 medicine from the community pharmacy, parents/adult relatives or home medicine cabinet under adult supervision during the preceding 3 months. On the other hand, a total of $104(24.3 \%)$ students had taken at least 1 medicine from friends/young relatives or from the home medicine cabinet without guidance during the same period of time.

\section{DISCUSSION}

The study showed that the prevalence of selfreported health complaints during the 3 months prior to the study had been quite high among Maltese adolescents. This is consistent with previous research carried out in Slovakia ${ }^{4}$, although direct comparisons are difficult to make due to differences in the methodologies used. The psychological stresses associated with the changes that occur during adolescence, often take the form of headaches and gastrointestinal problems. ${ }^{1,20}$ This could explain the high prevalence of these 2 health complaints in this study (Table 1). This data is also consistent with previous research where the prevalence of headaches and digestive disorders during a 3-month period had been reported to be 90.9\% among Canadian adolescents and 34.6\% among Chinese adolescents respectively. ${ }^{3,9}$

The high prevalence of ear problems/hay fever /cold/cough that was reported in this study could be related to the winter and spring months for which the students were asked to record their health complaints. $^{19,21}$ More than half of the female population (59.6\%) had experienced menstrual pain. This finding is similar to that reported among female adolescents in Canada (58.6\%). ${ }^{3}$ About a third of the study population complained of skin problems, possibly due to the common occurrence of acne that accompanies hormonal changes during puberty. ${ }^{22}$ However, it is interesting to note that a study carried out among adolescents in a district in Hong Kong, reported a much lower prevalence of skin problems $(9.5 \%)$, headache/ dizziness $(23.6 \%)$ and menstrual pain (13.8\% of girls). ${ }^{9}$ This difference could stem from cultural differences in the perception of health, especially from the popular use of alternative methods for the maintenance of health among the Chinese. ${ }^{23}$

Although the utilization of different recall periods by other researchers, limits the extent to which comparisons can be made, the high prevalence of medicine consumption that was reported in this study is supported by the findings of other research studies. ${ }^{4,7,10,12,13}$ Possibly the high level of medicine consumption in this study was related to the high prevalence of self-reported health complaints. In fact, a statistically highly significant positive correlation was found between medicine consumption and the number of self-reported health complaints for both genders. Furthermore, the order of prevalence of medicine consumption for the individual health complaints agreed very closely with the order of the related symptom prevalence (Table 1).

The great majority of the students obtained their medicines from a community pharmacy (Table 2 ). However, the source that was mostly accessed by students who had complained of headache and menstrual pain was the home medicine cabinet (53.9\% and $60.0 \%$ respectively). These values are concordant with research carried out in Canada where the proportions of adolescents who had accessed medicines for headache and menstrual pain from the home medicine cabinet during the preceding 3 months were $60.9 \%$ and $52.8 \%$ respectively. ${ }^{3}$ These results indicate the widespread use of analgesics in households.

A substantial proportion (14.3\%) of students who had taken antibiotics during the preceding 3 months had obtained them from parents/ adult relatives. In 
addition, $9.9 \%$ of the students who had taken antibiotics had obtained them from the home medicine cabinet. These results suggest that family members may not have been taking full courses of these prescription medicines, keeping the surplus for later use with ease of access to other family members. This situation does not seem to be unique to Malta. A study which had been carried out in Russia, revealed that antibiotics were widely stocked in home medicine cabinets and used in an uncontrolled manner. ${ }^{24}$ Another study carried out among adults in the US showed that $25.7 \%$ of the participants kept any antibiotics left over from a prescription that had not been completed. ${ }^{25}$ Half of these adults would take or had taken the leftover antibiotics for self-diagnosed illness and $6.9 \%$ of the total sample would even share or had shared the antibiotic with a friend or family member. The imprudent use of antibiotics and lack of knowledge about appropriate antibiotic use contributes to the emergence and spread of anti-microbial resistance. $^{26}$

In this study, for each medicine studied, less than $4.0 \%$ of the students had obtained it from a friend or young relative. For instance, the proportions of students who had obtained medicines from their peers for headache and menstrual pain were $3.2 \%$ and $1.4 \%$ respectively. This contrasts with research carried out in Canada were the proportions of adolescents who had accessed medicines for headache and menstrual pain from their peers during a 3-month period were $10.6 \%$ and $14.8 \%$ respectively. ${ }^{3}$ These data suggest a relatively greater element of caution in borrowing medicines among the Maltese students in this study. This result may stem from the fact that cultural differences may exist between adolescents in different countries.

In most cases, the participants had obtained medicines with adult guidance. Nevertheless, a substantial $24.3 \%$ of those who had used medicines during the preceding 3 months, reported that, at some time during this period they had taken medicines without adult guidance. This high prevalence of autonomously administered medication by adolescents had been previously reported by other researchers. ${ }^{3,8}$ Given the potential teratogenic effects of some medicines, autonomous medication poses a possible risk for girls who are entering their reproductive years. ${ }^{27}$ The query emerges not as to whether adolescents should selfmedicate but how to ensure that adolescents possess appropriate knowledge to use medicines responsibly. Otherwise, without knowing, these individuals might be faced with considerable health risks.

This study has both its strengths and weaknesses. A major strength of the study is that since selfreported health complaints are based on perceptions of health, they may be more appropriate in relation to medicine seeking behaviour during adolescence than health indicators based on medical records or medical statistics. ${ }^{5}$ Another strength of this study is that the gender distribution and socioeconomic status of the students was concordant with national data. ${ }^{18,28}$ This observation indicates that the findings in this study sample are likely to be representative of the health complaints and medicine use of the whole population of 15 year-olds in Malta. The study also had its limitations. First, the use of self-administered questionnaires relies on retrospective information to be given honestly and accurately by the respondents. Furthermore, it was not possible to conduct individual non-response studies with students who were absent on the days of data collection because of the requirement of anonymity. According to the information in school records, the students were away due to sickness. However, considering that almost $93.0 \%$ of the enrolled selected population was present, it is probable that the present data may only slightly misrepresent the health complaints and use of medicines by Maltese adolescents.

\section{CONCLUSIONS}

The results of this study show a high prevalence of self-reported health complaints and widespread use of medicines among adolescents in Malta. In most cases, the participants had obtained medicines with adult guidance. However, a substantial proportion of students had obtained medicines autonomously. These findings highlight the need for educating Maltese adolescents about the proper use of medicines.

\section{ACKNOWLEDGEMENTS}

The authors would like to thank Dr. Andrew Amato Gauci, MD, MSc, from the European Centre for Disease Prevention and Control (ECDC), Stockholm, Sweden and Dr. Doriette Soler, MD, MSc from the Department of Health, Malta, for their help in planning this study.

\section{CONFLICT OF INTEREST}

None declared.

\section{References}

1. King A, Wold B, Tudor-Smith C, Harel Y. Health behaviour in school-aged children. Copenhagen, WHO Regional Publications; 1996:58-83.

2. Campbell A, McGrath PJ. Use of medication by adolescents for the management of menstrual discomfort. Arch Pediatr Adolesc Med. 1997;151(9):905-913.

3. Chambers CT, Graham JR, McGrath PJ, Finley A. self-administration of over-the-counter medication for pain among adolescents. Arch Pediatr Adolesc Med. 1997;151(5):449-555.

4. Geckova A, Tuinstra J, Pudelsky M, Kovarova M, van Dijk JP, Groothoff JW, Post D. Self-reported health problems of Slovak adolescents. J Adolesc. 2001;24(5):635-645. 
5. Torsheim T, Danielson M, Valimaa R. Health and well-being. In: Currie C, Roberts C, Morgan A, Smith R, Settertobulte W, Samdal O, Barnekow Rasmussen V, editors. Young people's health in context. Health behaviour in school-aged children (HBSC): international report from the 2001/2002 survey. Copenhagen: World Health Organisation; 2004. p. 5562.

6. Schirm E, van den Berg P, Gebben H, Sauet P, de Jong-van den Berg L. Drug use of children in the community assessed through pharmacy dispensing data. Br J Clin Pharmacol. 2000;50(5):473-478.

7. Dengler R, Roberts H. Adolescents' use of prescribed drugs and over-the-counter preparations. J Public Health Med. 1996;18(4):437-442.

8. Geissler PW, Nokes K, Prince RJ, Achieng Odhiambo R, Aagaard-Hansen J, Ouma JH. Children and medicines: selftreatment of common illnesses among Luo schoolchildren in western Kenya. Soc Sci Med. 2000;50(12):1771-1783.

9. Lau TF, Yu A, Cheung JCK, Leung SF. Studies on common illnesses and medical care utilization patterns of adolescents in Hong Kong. J Adolesc Health. 2000;27(6):443-452.

10. Stoelben S, Krappweis J, Rossler G, Kirch W. Adolescents' drug use and drug knowledge. Eur J Pediatr. 2000;159(8):608-614.

11. Hansen $E H$, Holstein $B E$, Due $P$, Currie $C E$. International survey of self-reported medicine use among adolescents. Pediatrics. 2003;37(3):361-366

12. Abahussain E, Matowe LE, Nicholls PJ. Self-reported medication use among adolescents in Kuwait. Med Princ Pract. 2005;14(3):161-164

13. da Silva C, Giugliani ER. Consumption of medicines among adolescent students: a concern. J Pediatr (Rio J). 2004;80(4):326-332.

14. lannotti RJ, Bush PJ. The development of autonomy in children's health behaviours. In: Sussman EJ, Feagans W, Ray W, editors. Emotion, Cognition, Health and Development in Children and Adolescents. New York: Erlbaum; 1989. p. 5374.

15. Daniel KL, Honein MA, Moore CA. Sharing prescription medication among teenage girls: potential danger to unplanned/undiagnosed pregnancies. Pediatrics. 2003;111(5):1167-1170.

16. Hameen-Anttila K, Juvonen M, Ahonen R, Bush PJ, Airaksinen M. What schoolchildren should be taught about medicines. Health Educ. 2006;105(6):424-436.

17. HBSC focus groups. International standard version of 2001/02 HBSC mandatory questionnaire. In: Currie C, Samdal O, Smith B, editors. Health behaviour in school-aged children: a World Health Organization cross-national study. Research protocol for the 2001/02 Survey. Edinburgh: University of Edinburgh; 2001. p. 213-234.

18. Boyce W, Dallago L. Socioeconomic inequality. In: Currie C, Roberts C, Morgan A, Smith R, Settertobulte W, Samdal O, Barnekow Rasmussen V, editors. Young people's health in context. Health behaviour in school-aged children (HBSC): international report from the 2001/2002 survey. Copenhagen: World Health Organisation; 2004. p. 13-25.

19. Laforest L, Bousquet J, Pietri G, Sazonov Kocevar V, Yin D, Pacheco Y, Van Ganse E. Quality of life during pollen season in patients with seasonal allergic rhinitis with or without asthma. Int Arch Allergy Immunol. 2005;136(3):281-286.

20. Kamolz T, Pointner R. Gastroesophogeal reflux disease. Heart-burn from a psychological view. Minerva Gastroenterol Dietol. 2004;50(3):261-268.

21. Monto AS. The seasonality of rhinovirus infections and its implications for clinical recognition. Clin Ther. 2002;24(12):1987-1989.

22. Webster GF. The pathophysiology of acne. Cutis 2005;76:4-7.

23. Bi P, Tong S, Parton KA. Family self-medication and antibiotics abuse for children and juveniles in a Chinese city. Soc Sci Med. 2000;50(10):1445-1450.

24. Stratchounski LS, Andreeva IV, Ratchina SA, Galkin DV, Petrotchenkova NA, Demin AA, Kuzin VB, Kusnetsova ST, Lithatcheva RY, Nedogoda SV, Ortenberg EA, Belikov AS, Toropova IA. The inventory of antibiotics in Russian home medicine cabinets. Clin Infect Dis. 2003;37(4):498-505.

25. Ceaser S, Wurtz R. "Leftover" antibiotics in the medicine cabinet. Ann Intern Med. 2000;133(1): 74.

26. Todar K. Todar's online textbook of bacteriology [Internet]. Wisconsin: University of Wisconsin, Department of Bacteriology; 2008. Bacterial resistance to antibiotics;[cited 2008 May 19]; [about 38220 bytes]. Available from: http://www.textbookofbacteriology.net/resantimicrobial.html

27. Banhidy F, Lowry RB, Czeizel AE. Risk and benefit of drug use during pregnancy. Int J Med Sci. 2005;2(3):100-106.

28. Population and social statistics unit. Demography review 2004: population and social conditions. Malta: National statistics unit; 2005. 